$e-I S S N$ : 2621-4105

\title{
PELAKSANAAN OTONOMI DESA PASCA UNDANG-UNDANG NOMOR 6 TAHUN 2014 TENTANG DESA
}

\author{
Bambang Adhi Pamungkas \\ Magister Hukum Univeritas Semarang, Semarang \\ bambangadhip24@gmail.com
}

\begin{abstract}
ABSTRAK
Penelitian ini bertujuan untuk mengetahui dan menganalisa pelaksanaan otonomi desa pasca penerbitan undang-undang. Desa adalah suatu wilayah yang ditempati oleh komunitas kelompok manusia dan saling melakukan interaksi antara satu sama lainnya, memiliki tatanan sosial yang mengatur kehidupan masyarakatnya melalui tradisi, adat istiadat dan hukum yang relatif mandiri. Lahirnya UU Nomor 6 Tahun 2016 tentang Desa memberikan keluwesan pada pemerintahan Desa dalam menjalankan pemerintahannya sendiri secara demokrtis. Melalui asas rekognisi dan subsidiaritas, Pemerintahan Desa dijalankan berdasarkan otonomi dan hak asalusul. Penelitian ini menggunakan metode yuridis normatif dengan spesifikasi penelitian yang bersifat deskriptis analitis. Jenis data yang digunakan dalam penelitian ini adalah data sekunder, yaitu data yang diperoleh melalui bahan hukum primer, sekunder dan tersier. Simpulan dari hasil penelitian ini adalah penyelenggaraan pemerintahan desa merupakan subsistem dari sistem penyelenggaraan pemerintahan sehingga desa memiliki kewenangan dan mengurus kepentingan masyarakatnya melalui perencanaan pembangunan desa diselenggarakan dengan mengikut sertakan masyarakat desa melalui musyawarah perencanaan pembangunan desa serta agar Desa dapat terintegrasi dan dilaksanakan dengan baik, pemerintah harus segera melakukan revisi yang ada dalam UU Desa, antara lain terhadap norma hukum yang masih menimbulkan konflik baik vertikal maupun horizontal serta perlu adanya pembahasan yang jelas dalam perubahan UndangUndang Desa antara kewenangan Kemendagri dan Kementrian desa terkait program pembangunan.
\end{abstract}

Kata Kunci: Desa; Otonomi Desa; Pelaksanaan 
$e-I S S N$ : 2621-4105

\title{
IMPLEMENTATION OF THE POST-REGULATION AUTONOMY OF VILLAGE NUMBER 6 OF 2014 CONCERNING VILLAGE
}

\author{
Bambang Adhi Pamungkas \\ Master of Law, Semarang University Law, Semarang \\ bambangadhip24@gmail.com
}

\begin{abstract}
This study aims to determine and analyze the implementation of village autonomy after the issuance of the law. Village is a region that is occupied by human groups that interacts with one another, having a social order that regulates the society life through traditions, customs and laws that is relatively independent. The raise of Law No 6 of 2016 concerning village gives flexibility to the village government in conducting its own rule democratically. Through the concepts of recognition and subsidiarity, the village government is running based on autonomy and the right of origin. This research used normative juridical methods with analytical descriptive research specifications. The data used in this research is the secondary data that was obtained through primary, secondary and tertiary law materials. The results of this research is that the implementation of village government is a subsystem of the governance system. It means that the village has authority and management to community needs through the village development planning by involving the village community through meetings so that the village can be integrated and implemented well. The Government have to immediately revise various conflicting rules that exist in the Village Law, including the laws and norms that resulted conflicts both vertically and horizontally. Needed a clear discussion in the Village Law revision between the Ministry of Home Affairs authority and the Minister of Village in the field of development program.
\end{abstract}

Keywords: Village; Village Autonomy; Implementation. 
$e-I S S N$ : 2621-4105

\section{A. PENDAHULUAN}

Indonesia sebagai negara kesatuan tersusun atas pemerintahan pusat dan daerah, yang secara spesifik diatur dalam Pasal 18 ayat (1) Undang-Undang Dasar Negara Kesatuan Republik Indonesia Tahun 1945 yang menyatakan, Negara Kesatuan Republik Indonesia dibagi atas daerah-daerah provinsi dan daerah provinsi itu dibagi atas kabupaten dan kota, yang tiap-tiap provinsi, kabupaten, dan kota itu mempunyai pemerintahan daerah yang diatur dengan Undang-undang. Pasca Reformasi 1998, melalui amandemen UUD 1945, kewenangan pemerintah pusat dan daerah mengalami perubahan yang begitu signifikan. Demikian itu terlihat dalam sistem ketatanegaraan dari sentralisasi menuju arah desentralisasi.

Status Pemerintah Daerah dan Desa, secara konstitusional telah diatur dalam UUD 1945, serta peraturan perundang-undangan lainnya mengenai Pemerintahan Daerah dan Pemerintahan Desa sejak awal kemerdekaan sampai pasca Reformasi hingga saat ini. Dalam konstitusi Indonesia, yang mengatur tentang Pemerintahan Daerah secara spesifik dibahas dalam Pasal 18 UUD NRI Tahun 1945. Penjelasan dari Pasal 18 Undang-undang Dasar 1945 tersebut menyebutkan bahwa daerah Indonesia akan dibagi dalam daerah propinsi dan daerah propinsi akan dibagi pula dalam daerah yang lebih kecil. Daerah-daerah yang bersifat otonom (streak dan locale rechtsgemen-schappen) atau bersifat daerah administrasi belaka, semuanya menurut aturan yang akan ditetapkan dengan undang-undang. Di daerah yang bersifat otonom akan diadakan Badan Perwakilan Daerah oleh karena di daerah pun pemerintahan akan bersendi atas dasar permusyawaratan.

Keberadaan Desa secara yuridis formal diakui dalam Undang-Undang Republik Indonesia Nomor 9 Tahun 2015 Tentang Perubahan Kedua Atas UndangUndang Nomor 23 Tahun 2014 Tentang Pemerintahan Daerah, untuk selanjutnya disebut dengan UU No. 9 Tahun 2015 dan Peraturan Pemerintah Nomor 72 Tahun 2005 tentang Desa serta Undang-Undang Republik Indonesia Nomor 6 Tahun 2014 Tentang Desa. Berdasarkan ketentuan ini maka desa dapat menjalankan kekuasaannya yang lebih luas untuk mengatur dan mengurus sendiri urusan 
pemerintah berdasarkan asas otonomi dan tugas pembantuan. Namun UU No. 9 Tahun 2015 ini secara garis besar masih terlalu umum mengatur tentang Desa, akibatnya pengelolaan Desa menjadi lamban karena harus menunggu Peraturan Pemerintah di atasnya. Oleh karenanya maka lahirlah Undang-Undang Republik Indonesia Nomor 6 Tahun 2014 Tentang Desa, yang untuk selanjutnya Penulis sebut sebagai UU Desa.

Terlepas dari kronologi tarik ulurnya kepentingan politik lahirnya UU Desa tersebut, respon lahirya justru lebih menyorot pada pendanaan, atau besaran dana yang didapatkan masing-masing desa. Padahal masih banyak hal yang juga "urgent" selain urusan pendanaan yang menjadi tolak ukur kesejahteraan dari amanat undang-undang tersebut.

Sebagaimana diketahui bahwa desa adalah kesatuan masyarakat hukum yang memiliki batas wilayah yang berwenang untuk mengatur dan mengurus urusan pemerintahan, kepentingan masyarakat setempat berdasarkan prakarsa masyarakat, hak asal usul, dan/atau hak tradisional yang diakui dan dihormati dalam sistem pemerintahan Negara Kesatuan Republik Indonesia.

Untuk mengembalikan eksistensi desa sebagai kesatuan masyarakat hukum yang keduduknnya masih kabur, UU Desa ini memberikan keluwesan dalam menjalankan pemerintahannya sendiri secara demokrtis. Melalui asas rekognisi dan subsidiaritas, Pemerintahan Desa dijalankan berdasarkan otonomi dan hak asal-usul.

\section{B. PERMASALAHAN}

1. Bagaimana pelaksanaan otonomi desa pasca Undang-Undang Nomor 6 Tahun 2014 Tentang Desa?

2. Apakah problematika yang dihadapi dan solusi atas pelaksanaan otonomi desa pasca Undang-Undang Nomor 6 Tahun 2014 Tentang Desa ?

\section{TINJAUAN PUSTAKA}

\section{Pengertian Desa Secara Umum}

Istilah Desa sendiri menurut Koentjaraningrat diambil dari bahasa sansekerta yang berartikan tanah, tumpah darah. Selanjutnya, pengertian Desa menurut Kamus 
Besar Bahasa Indonesia adalah kesatuan wilayah yang dihuni oleh sejumlah keluarga yang mempunyai sistem pemerintahan sendiri (dikepalai oleh seorang Kepala Desa) atau desa merupakan kelompok rumah di luar kota yang merupakan kesatuan. ${ }^{1}$

Hanif Nurcholis memberikan pengertian tentang Desa adalah suatu wilayah yang ditingali oleh sejumlah orang yang saling mengenal, hidup bergotong royong, memiliki adat istiadat yang relatif sama, dan mempunyai tata cara sendiri dalam mengatur kehidupan kemasyarakatannya, ${ }^{2}$ sedangkan R Bintarto mendefinisikan Desa sebagai perwujudan geografis yang ditimbulkan oleh unsur-unsur fisiografis, sosial, ekonomis politik, serta kultural setempat dalam hubungan dan pengaruh timbal balik dengan daerah lain. ${ }^{3}$

Dengan definisi tersebut, UU Desa telah menempatkan desa sebagai organisasi campuran (hybrid) antara masyarakat berpemerintahan (self governing community) dengan pemerintahan lokal (local self government). Dengan begitu, sistem pemerintahan di desa berbentuk pemerintahan masyarakat atau pemerintahan berbasis masyarakat dengan segala kewenangannya (authority). Desa juga tidak lagi identik dengan pemerintah desa dan kepala desa, melainkan pemerintahan desa yang sekaligus pemerintahan masyarakat yang membentuk kesatuan entitas hukum. Artinya, masyarakat juga mempunyai kewenangan dalam mengatur desa sebagaimana pemerintahan desa. ${ }^{4}$

\section{Pemerintahan Desa}

Pemerintah adalah perangkat (organ) negara yang menyelenggarakan pemerintahan, sedangkan pemerintahan adalah kegiatan yang diselenggarakan oleh perangkat negara, yaitu pemerintah, sehingga dapat diartikan bahwa Pemerintahan

\footnotetext{
${ }^{1}$ https://jagokata.com/arti-kata/desa.html diakses pada tanggal 7 Agustus 2019 pukul 19:57 wib

2 Hanif Nurcholis, Pertumbuhan dan Penyelenggaraan Pemerintahan Desa, (Jakarta : Erlangga, 2011) hlm. 4

${ }^{3}$ R. Bintarto, Geografi Desa, (Yogyakarta : Up.Spring, 1989) hlm. 4

${ }^{4}$ M Salahudin, Kewenangan Desa dan Regulasi Desa, Cetakan Pertama, Jakarta : Kemernterian Desa PDTT RI 2015), hlm. 11-12
} 
Desa adalah sebagai kegiatan dalam rangka penyelenggaraan pemerintahan yang dilaksanakan oleh perangkat atau organisasi pemerintahan, yaitu Pemerintahan Desa.

Pemerintahan desa berdasarkan Pasal 1 Ayat (2) PP No. 43 Tahun 2014 Tentang Peraturan Pelaksanaan Undang-Undang Nomor 6 Tahun 2014 Tentang Desa adalah penyelenggaraan urusan pemerintahan dan kepentingan masyarakat setempat dalam sistem pemerintahan Negara Kesatuan Republik Indonesia.

Pemerintah desa adalah kepala Desa atau yang disebut dengan nama lain dibantu perangkat Desa sebagai unsur penyelenggara Pemerintahan Desa. ${ }^{5}$

Fungsi pengawasan BPD meliputi pengawasan terhadap pelaksanaan Peraturan Desa, Anggaran Pendapatan dan Belanja Desa, dan Keputusan Kepala Desa. Pelaksanaa Peraturan Desa ditetapkan dengan keputusan Kepala Desa.

Dalam penyelenggaraan pemerintahan, pemerintahan desa membutuhkan sumber keuangan dan pendapatan desa. Keuangan desa adalah semua hak dan kewajiban desa yang dapat dinilai dengan uang serta segala sesuatu berupa uang dan barang yang berhubungan dengan pelaksanaan hak dan kewajiban desa. ${ }^{6}$ Hak dan kewajiban sebagaimana yang dimaksud tersebut menimbulkan pendapatan, belanja, pembiayaan, dan pengelolaan keuangan desa.

\section{Dana Desa}

Dana desa adalah dana yang bersumber dari APBN yang diperuntukkan bagi yang ditransfer melalui APBD kabupaten dan kota yang digunakan untuk membiayai penyelenggaraan pemerintahan, pelaksanaan pembangunan, pembinaan

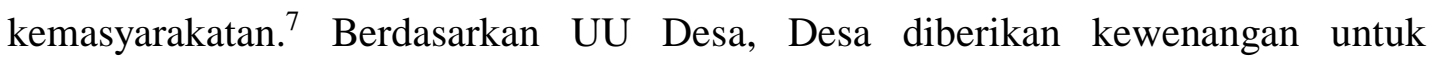
mengatur dan mengurus kewenangannya sesuai dengan kebutuhan dan prioritas desa.

\footnotetext{
${ }^{5}$ Pasal 1 Ayat (3) PP No. 43 Tahun 2014 Tentang Peraturan Pelaksanaan Undang-Undang Nomor 6 Tahun 2014 Tentang Desa

${ }^{6}$ Ibid. Pasal 71 Ayat (1)

${ }^{7}$ Peraturan Menteri Keuangan Republik Indonesia Nomor 241 Tahun 2014 pasal 1 tentang Pelaksanaan Pertanggungjawaban Transfer ke Daerah dan Dana Desa.
} 
Menurut Pasal 18 Peraturan Menteri Dalam Negeri Nomor 37 Tahun 2007 tentang Pedoman Pengelolaan Keuangan Desa bahwa Anggaran Dana Desa berasal dari APBD Kabupaten/Kota yang bersumber dari bagian Dana Perimbangan Keuangan Pusat dan Daerah yang diterima oleh Kabupaten/Kota untuk desa paling sedikit $10 \%$ (sepuluh persen).

Berdasarkan Pasal 11 Ayat (1) Peraturan Pemerintah No 60 Tahun 2014, Dana Desa setiap kabupaten/kota dialokasikan berdasarkan perkalian antara jumlah di setiap kabupaten/kota dan rata-rata Dana Desa setiap provinsi. Rata-rata Dana Desa setiap provinsi dialokasikan berdasarkan jumlah desa dalam provinsi yang bersangkutan serta jumlah penduduk kabupaten/kota, luas wilayah kabupaten/kota, angka kemiskinan kabupaten/kota, dan tingkat kesulitan geografis kabupaten/kota dalam provinsi yang bersangkutan. Besaran Dana desa di setiap Desa sebagaimana dimaksud dalam Pasal tersebut, dihitung berdasarkan jumlah penduduk desa, luas wilayah desa, angka kemiskinan desa dan tingkat kesulitan geografis.

\section{Otonomi Desa}

Otonomi desa merupakan otonomi asli, bulat, dan utuh serta bukan merupakan pemberian dari Pemerintah. ${ }^{8}$ Juliantara menerangkan bahwa otonomi desa bukanlah sebuah kedaulatan melainkan pengakuan adanya hak untuk mengatur urusan rumah tangganya sendiri dengan dasar prakarsa dari masyarakat. Otonomi dengan sendirinya dapat menutup pintu intervensi institusi diatasnya, sebaliknya tidak dibenarkan proses intervensi yang serba paksa, mendadak, dan tidak melihat realitas komunitas. ${ }^{9}$

Tugas utama pemerintah dalam rangka otonomi desa adalah menciptakan kehidupan demokratis, memberi pelayanan publik dan sipil yang cepat dan membangaun kepercayaan masyarakat menuju kemandirian desa, untuk itu desa tidak dikelola secara teknokratis tetapi harus mampu memadukan realita kemajuan

${ }^{8}$ H.A.W. Widjaja, Otonomi Desa : Merupakan Otonomi Yang Asli, Bulat dan Utuh, (Jakarta : Rajawali Pers, 2008) hlm. 165

${ }^{9}$ Dadang Juliantara, Pembaharuan Desa, Bertumpu Pada Angka Terbawah (Yogyakarta : Lappera Pustaka Utama, 2003) hlm 116 
teknologi yang berbasis pada sistem nilai lokal yang mengandung tata aturan, nilai, norma, kaidah, dan pranata-pranata sosial lainnya. Potensi-potensi desa berupa hak tanah (tanah bengkok, titisari dan tanah-tanah khas Desa lainnya), potensi penduduk, sentra-sentra ekonomi dan dinamika sosial-politik yang dinamis itu menuntut kearifan dan professionalisme dalam pengelolaan desa menuju optimalisasi pelayanan, pemberdayaan, dan dinamisasi pembangunan masyarakat desa.

\section{Hubungan Otonomi Daerah dengan Otonomi Desa}

Otonomi Daerah merupakan perwujudan pelaksanaan asas desentralisasi dalam penyelenggaraan pemerintahan suatu negara. Berdasarkan asas tersebut kekuasaan negara akan terbagi antara Pemerintah Pusat disatu pihak dan Pemerintah Daerah dilain pihak.

Negara Republik Indonesia sebagai Negara kesatuan menganut asas desentralisasi dalam penyelenggaraan pemerintahan, dengan memberikan kesempatan dan keleluasaan kepada Daerah untuk menyelenggarakan Otonomi daerah. Karena itu, pasal 18 UUD NKRI Tahun 1945, antara lain, menyatakan bahwa pembagian Daerah Indonesia atas dasar besar dan kecil, dengan bentuk dan susunan pemerintahannya ditetapkan dengan undang-undang. Dalam kaitannya otonomi desa, dikuatkan dengan bunyi pasal 18 B ayat (1) UUD NKRI Tahun 1945 yang menyatakan bahwa "Negara mengakui dan menghormati satuan-satuan pemerintah daerah yang bersifat khusus atau bersifat istimewa yang diatur dengan undang-undang."

Kehadiran kebijakan Otonomi Daerah yang diterapkan melalui UndangUndang Nomor 23 Tahun 2014 Tentang Pemerintah Daerah sebagaimana diubah dengan Undang-Undang Nomor 9 Tahun 2015 Tentang Perubahan Kedua Atas Undang-Undanng Nomor 23 Tahun 2014 Tentang Pemerintahan Daerah diharapkan akan memberikan wewenang yang besar kepada Daerah untuk mengatur wilayahnya sesuai dengan aspirasi masyarakatnya. Undang-Undang ini diangap berwatak demokratis karena didalamnya memuat aturan yang dianggap akan memberikan jalan bagi terjadinya proses pemberdayaan bagi masyarakat di daerah 
termasuk masyarakat Desa. Karena Undang-undang ini juga memuat kebijakan mengenai desa yang mengarah kepada adanya Otonomi Desa yang luas.

Kebijakan Otonomi Daerah ini diharapkan mampu meningkatkan taraf hidup bagi masyarakat di desa. Impian yang sangat diharapkan dari masyarakat desa dengan adanya kebijakan ini adalah masyarakat diberi kewenangan dan tanggungjawab atas pemanfaatan sumberdaya alam yang ada didesanya dan bagi hasil atas pemanfaatan sumber daya alam dan sumber daya lainnya. Kebijakan ini bagi masyarakat desa dianggap akan memberikan kesempatan kepada Pemerintah Daerah untuk lebih dapat memajukan masyarakatnya melalui berbagai langkah-langkah kebijakan yang sesuai dengan kondisi dan kebutuhan masyarakat di wilayahnya.

\section{METODE PENELITIAN}

\section{Metode Pendekatan}

Metode pendekatan yang peneliti gunakan adalah pendekatan perundangundangan (statute approach). Metode pendekatan perundang-undangan (statute approach) ini dilakukan dengan cara menelaah semua undang-undang dan regulasi yang berkaitan dengan Pemerintahan Daerah dan Pemerintahan Desa

\section{Spesifikasi Penelitian}

Penelitian ini lebih mengarah kepada spesifikasi penelitian yang deskriptis analitis, dimana Penulis mendeskripsikan atau memberikan gambaran terhadap data yang diteliti, dalam hal ini pelaksanaan otonomi serta bagaimana problematika yang dihadapi dan solusinya pasca diterbitkannya UU Desa.

\section{Jenis Data}

Jenis data yang digunakan dalam penelitian ini adalah data sekunder, yaitu data yang diperoleh melalui bahan hukum primer, sekunder dan tersier.

\section{Metode Pengumpulan Data}

Metode pengumpulan data yang Penulis gunakan dalam penelitian tentang Pelaksanaan Otonomi Desa Pasca Undang-Undang Nomor 6 Tahun 2014 Tentang Desa ini adalah penelitian kepustakaan (literature research) dan juga melalui 
penelitian melalui internet (internet research). Data kepustakaan ini Penulis peroleh dari peraturan perundang-undangan, buku-buku, dokumen resmi, publikasi dan hasil penelitian yang berkaitan dengan permasalahan dalam penelitian ini. Sedangkan penelitian melalui internet ini Penulis lakukan dengan menggunakan search enggine (mesin pencari) untuk menemukan bahan-bahan hukum baik primer maupun sekunder.

\section{Metode Analisis Data}

Analisis normatif kualitiatif Penulis gunakan untuk menganalisis permasalahan dalam penelitian tentang "Pelaksanaan Otonomi Desa Pasca UndangUndang Nomor 6 Tahun 2014 Tentang Desa" Dalam mendeskripsikannya, Penulis membuat ulasan serta telaah kritis mengenai konsep-konsep dan teori-teori yang dikemukakan oleh para ahli terhadap komparasi perundang-undangan dalam kaitannya terhadap pelaksanaan otonomi desa, hubungan otonomi daerah dengan otonomi desa untuk menggiring opini yang dapat dijadikan rujukan untuk menyelesaikan permasalahan hukum yang menjadi objek kajian dalam penelitian.

\section{E. PEMBAHASAN}

\section{Pelaksanaan Otonomi Desa Pasca UU No 6 Tahun 2014 Tentang Desa}

Undang-Undang Nomor 23 Tahun 2014 Tentang Pemerintah Daerah sebagaimana diubah dengan Undang-Undang Nomor 9 Tahun 2015 Tentang Perubahan Kedua Atas Undang-Undanng Nomor 23 Tahun 2014 Tentang Pemerintahan Daerah memberikan wewenang yang besar kepada Daerah untuk mengatur wilayahnya sesuai dengan aspirasi masyarakatnya. Undang-Undang ini berwatak demokratis karena didalamnya memuat aturan yang dianggap akan memberikan jalan bagi terjadinya proses pemberdayaan bagi masyarakat di daerah termasuk masyarakat Desa. Karena Undang-undang ini juga memuat kebijakan mengenai desa yang mengarah kepada adanya Otonomi Desa yang luas.

Lahirnya UU Desa pada 15 Januari 2014 yang lalu merupakan terobosan baru dengan semangat melakukan akselerasi kesejahteraan masyarakat desa, yang secara terstruktur sedemikian rupa mengatur mulai dari penataan desa, penyelenggaraan 
pemerintahan desa, hak dan kewajiban desa dan masyarakat desa, peraturan desa, keuangan desa dan asset desa, pembangunan desa dan kawasan pedesaan, badan usaha milik desa, kerjasama desa, lembaga kemasyarakatan desa dan lain sebagainya.

Pengaturan desa memiliki 13 (tiga belas) prinsip atau asas yang harus dijadikan perhatian oleh para pemangku kepentingan dalam melakukan pengaturan desa. Sejatinya prinsip atau asas ini lebih dikedepankan para pengambil kebijakan ketika hendak merumuskan regulasi di bawah UU Desa.

Salah satu kekuatan UU Desa dari ketiga belas asas tersebut adalah asas subsidiaritas dan asas rekognisi. Dua kekuatan itu membuat desa memiliki kekuatan untuk mengatur dirinya sendiri berdasar aset dan potensi yang dimilikinya.

Asas rekognisi yaitu bentuk pengakuan dan penetapan desa berdasarkan asalusul, sedangkan asas subsidiaritas yaitu bentuk pengakuan dan penetapan kewenangan pemerintah desa dalam mengelola dapur pemerintahannya sendiri yang bertujan pada kepentingan masyarakat desa. Hal ini menegaskan bahwa Desa dengan UU Desa ini memiliki posisioning yang otonom, desa diakui sebagai hak asal usul, seperti penjelasan sebelumnya bahwa desa sejak dulu sudah otonom, dan asas subsidioritas, kewenangan yang berskala lokal desa dalam mengatur segala aktivitas penyelenggaraanya.

Bagi sebagian besar aparat desa, otonomi adalah suatu peluang baru yang dapat membuka ruang kreativitas bagi mereka dalam mengelola pengembangan desa. Selain itu dari sisi masyarakat, poin penting yang dirasakan didalam era otonomi adalah semakin transparannya pengelolaan pemerintahan desa dan semakin pendeknya rantai birokrasai dimana hal tersebut secara langsung maupun tidak langsung berpengaruh terhadap jalanya pembangunan desa dalam pengembanganya.

Penyelenggaraan pemerintahan desa merupakan subsistem dari sistem penyelenggaraan pemerintahan sehingga desa memiliki kewenangan dan mengurus kepentingan masyarakatnya. Maka selain memberikan posisi yang kuat kepada Kepala Desa seperti Kepala daerah, dalam UU Desa ini memperkenalkan lembaga 
baru yang disebut musyawarah desa yang merupakan sebuah forum permusyawaratan yang diikuti oleh BPD, Pemerintah Desa, dan unsur masyarakat desa untuk memusyawarahkan hal yang bersifat strategis. Artinya, setiap desa harus menghidupkan sebuah forum politik yang inklusif di mana persoalan strategis dimusyawarahkan bersama. Secara demikian diharapkan masyarakat desa akan berkembang menjadi komunitas yang kohesif.

Penyelenggaraan pemerintahan yang kuat hanya dapat terwujud jika partisipasi masyarakat lokal desa sangat tinggi dalam pembangunan desa. Perencanaan pembangunan desa diselenggarakan dengan mengikut sertakan masyarakat desa melalui musyawarah perencanaan pembangunan desa, yang menetapkan prioritas, program, kegiatan dan kebutuhan pembangunan desa yang didanai oleh Anggaran Pendapatan dan Belanja Desa, swadaya masyarakat desa, dan/ atau Anggaran Pendapatan dan Belanja Daerah kabupaten/Kota. Pembangunan desa dilaksanakan dengan semangat gotong royong serta memanfaatkan kearifan lokal dan sumber daya alam desa. Sementara itu, pelaksanaan program sektor yang masuk ke desa diinformasikan kepada pemerintah desa dan diintegrasikan dengan rencana pembangunan desa. Penyusunan APBDes dilakukan dengan melibatkan partisipasi masyarakat dan Informasi tentang keuangan desa secara transparan dapat diperoleh oleh masyarakat.

Pemerintah Desa juga berwenang untuk mendirikan Badan Usaha Milik Desa (BUMDes) yang dikelola dengan semangat kekeluargaan dan gotong-royong. BUMDes itu bisa bergerak di bidang ekonomi, pedagangan, pelayanan jasa maupun pelayanan umum lainnya sesuai ketentuan umum peraturan perundang-undangan.

Menyadari sangat pentingnya transparasi, UU Desa mengharuskan dikembangkannya sistem informasi desa yang bisa diakses oleh masyarakat desa dan semua pemangku kepentingan. Kebersamaan dan kohesivitas akan lebih mudah direalisasikan jika ditegakkan dengan transparansi. Masyarakat desa berhak mendapatkail info dan melakukan pemantauan mengenai rencana dan pelaksanaan pembangunan desa. 


\section{Problematika dan Solusi Atas Pelaksanaan Otonomi Desa Pasca Undang-} Undang Nomor 6 Tahun 2014 Tentang Desa

\subsection{Problematika di Bidang Penyelenggaraan Pemerintahan Desa}

Polemik hubungan secara kelembagaan Pasca UU Desa tidak hanya muncul pada tingkat Desa dan Kecamatan saja, 2 (dua) Kementerian pun saling mendalilkan kewenangannya untuk mengelola desa, yaitu Kementerian Dalam Negeri dan Kementerian Desa, Pembangunan Daerah Tertinggl dan Transmigrasi. Tarik menarik kewenangan urusan pedesaan antara Kemendagri dan Kemendesa masih menjadi polemik, karena keduanya mempunyai interpretasi yang berbeda terkait soal peraturan desa. Kemendagri yang mengurusi masalah desa sebelum Kemendesa berpegang pada UU Nomor 23 Tahun 2014 tentang Pemerintah Daerah dan UU Nomor 6 Tahun 2014 Tentang Desa. Adapun Kemendesa berpegang pada Perpres Nomor 7 Tahun 2015 tentang Organisasi Kementerian. Dalam Perpres tersebut menyebutkan bahwa Kementerian Desa, Pembangunan Daerah Tertinggl dan Transmigrasi termasuk dalam Kelompok Kementerian Negara, sehingga semua urusan kewenangan desa diinterpretasikan menjadi kewenangan Kementerian itu.

Persoalan lain dalam penyelenggaraan pemerintahan di Desa adalah terkait dengan tugas dan fungsi Kepala Desa serta hak dan Kewajiban dari Kepala Desa. Kepala Desa sebagai ujung tombak di Desa seringkali dianggap sebagai tokoh yang bisa menyelesaikan berbagai persoalan warga masyarakatnya. Kendalanya, Kepala Desa masih minim pengetahuan tentang hukum, utamanya yang paling dominan pada persoalan tanah. Mulai dari sengketa tanah antar warga, pengelolaan tanah kas desa dan yang paling banyak menyita perhatian adalah ketentuan Pasal 66 UU Desa tentang penghasilan Kepala Desa dan Perangkat Desa.

Hubungan yang tidak baik antara Kepala Desa dengan Sekretaris dan Perangkat Desa maupun BPD pun secara tidak langsung dapat mempengaruhi kinerja Kepala Desa dalam memberikan pelayanan bagi masyarakatnya. 


\subsection{Problematika di Bidang Pelaksanaan Pembangunan Desa}

Pasal 114 Ayat (1) PP Nomor 43 Tahun 2014 menyebutkan bahwa perencanaan pembangunan Desa disusun berdasarkan hasil kesepakatan dalam musyawarah Desa, kemudian dalam Pasal 116 Ayat (1) disebutkan pula bahwa dalam menyusun RPJMDes dan RKPDes, Pemerintah Desa wajib menyelenggarakan musyawarah perencanaan pembangunan Desa secara partisipatif. Akan tetapi hal tersebut dirasa kurang optimal dan hanya sebagai simbolik saja untuk memenuhi ketentuan Pasal 114 PP Nomor 43 Tahun 2014 karena seringkali usulan dalam musyawarah desa tersebut tidak terealisasikan.

Kasus tanah kas desa juga menjadi hambatan bagi pembangunan desa. Seperti telah dibahas dalam bab sebelumnya bahwa tanah kas desa termasuk dalam kekayaan asli desa. Kekayaan desa yang berupa tanah kas desa, di pulau jawa dipergunakan sebagai bengkok (penghasilan kepala desa dan perangkat desa) dan dipergunakan sebagai bondo desa (tanah kekayaan desa). Sebagai salah satu sumber pendapatan desa dan pendapatan perangkat desa, tanah kas desa mestinya merupakan tanah produktif. Namun pada kenyataannya tidak sedikit tanah kas desa yang dimiliki desa kondisinya tidak produktif sehingga akan mempengaruhi hasil produksinya. Dengan adanya UU Desa, terkait pengelolaan kekayaan milik desa mengalami perubahan yaitu dengan diundangkannya Peraturan Menteri Dalam Negeri Nomor 1 Tahun 2016 tentang Pengelolaan Aset Desa, yang memberi peluang bagi desa untuk dapat melaksanakan pemindahtanganan aset desa berupa tanah melalui tukar menukar. Dalam Permendagri tersebut pemindahtanganan aset desa berupa tanah tidak hanya yang akan digunakan untuk kepentingan umum, tetapi juga bukan untuk kepentingan umum, dan tanah kas desa selain untuk kepentingan umum dan bukan untuk kepentingan umum.

Kurangnya sosialisasi kebijakan dan penerapan fungsi-fungsi manajemen terhadap pengelolaan dana pada desa tidak optimal justru menimbulkan Kepala Desa terjerat kasus korupsi. Sedikitnya tercatat 181 kasus korupsi dengan 184 
tersangka korupsi dengan nilai kerugian sebesar 40,6 milyar rupiah. ${ }^{10}$ Sebagai contoh Desa Merden di Kabupaten Banjarnegara dimana Kepala Desa melakukan penyelewengan pendapatan desa yang berasal dari persewaan tanah bengkok dan tanah kas desa, dan Desa Wangandowo di Kabupaten Pekalongan dimana Kepala Desa melakukan penyelewengan pendapatan asli desa yang berasal dari penjualan sejumlah tanah dari desa kepada pihak ketiga yang hasil penjualannya tidak disetor ke kas desa.

\subsection{Problematika di Bidang Pembinaan Kemasyarakatan Desa}

Merencanakan, melaksanakan dan mengendalikan kegiatan pembinaan kemasyarakatan merupakan wewenang yang harus dikelola Desa. UU Desa tidak merinci dengan jelas kewenangan dan fungsi Kepala Desa untuk melakukan pembinaan kemasyarakatan baik dari segi mekanisme ataupun bentuk pelaksanaannya.

Tidak update nya monografi meneyebabkan Kepala Desa kesulitan dalam menerapkan kebijakan sosial, sedangkan dalam Pasal 86 UU Desa mengamanatkan Desa harus memiliki sistem informasi terkait dengan potensi yang ada, baik berupa potensi fisik maupun non fisik. Data-data yang valid dan selalu diperbaharui akan mempermudah pemerintah dalam menentukan arah kebijakan.

Pembangunan Desa skala lokal terkendala dengan pola kebijakan tata ruang perdesaan yang berpola top-down, sehingga tidak jarang menyebabkan desa kehilangan akses sumber daya akibat kebijakan tata ruang yang belum mengakomodir aspirasi desa.

\subsection{Problematika di Bidang Pemberdayaan Masyarakat Desa}

Program-program pemberdayaan yang ada pada pemerintahan desa sebelumnya sudah cukup bagus terutama sebagai sarana untuk mengentaskan

\footnotetext{
${ }^{10}$ Artikel Online, ICW : Ada 181 Kasus Korupsi Dana Desa Rugikan Negara Rp 40,6 Milliar, (https://nasional.kompas.com/read/2018/11/21/19000481/icw-ada-181-kasus-korupsi-dana-desa-rugikannegara-rp-406-miliar?page=all ),diakses pada tanggal 18 Agustus 2019 pukul 0:10 WIB
} 
kemiskinan di desa, sebagai contoh PNPM Mandiri. Akan tetapi hasil dari kegiatan kebanyakan masih berupa fisik, sehingga kurang memberikan pembelajaran bagi kemandirian. Selain itu, revitalisasi pada asas gotong royong dalam kegiatan pemberdayaan masyarakat perlu ditingkatkan, sebagai contoh beberapa kelompok masyarakat yang berhasil secara mandiri membangun usahanya seringkali berkembang sendiri tanpa memperdulikan kelompok lain. Persoalan status hukum usaha dan perlindungan hukum bagi hasil usaha pemberdayaan masyarakat juga masih menjadi hambatan.

Kegagalan lain dalam hal pemberdayaan masyarakat desa adalah anggapan dana stimulan dari pemerintah seringkali dijadikan ajang 'bancakan'. Paling banyak adalah bantuan untuk mendirikan koperasi simpan pinjam, akhirnya banyak sekali yang terjerat kasus pengelolaan dana bantuan simpan pinjam yang seringkali ditemukan bahwa pengelola adalah orang-orang terdekat Kepala Desa.

\subsection{Solusi Atas Pelaksanaan Otonomi Desa Pasca Undang-Undang Nomor 6}

\section{Tahun 2014 Tentang Desa}

Keputusan Pemerintah untuk membagi kewenangan Kementerian urusan desa kepada dua Kementerian berpotensi melanggar UU Desa. Solusi terbaik agar pelaksanaan UU Desa dapat terintegrasi dan dilaksanakan dengan baik, Pemerintah harus segera melakukan revisi dalam UU Desa, antara lain terhadap norma hukum yang masih menimbulkan konflik baik vertikal maupun horizontal, norma hukum yang tidak jelas, norma hukum yang masih kosong salah satu contohnya adalah Peraturan Desa tidak dibuat oleh Kepala Desa dan BPD akan tetapi hanya dibuat oleh Kepala Desa.

Kapasitas Desa dalam menyelenggarakan pembangunan masih terbatas. Keterbatasan itu dapat dideteksi pada aras pelaku (kapasitas aparat pemerintah desa dan masyarakat), kualitas tata kelola desa, maupun sistem pendukung (support sistem) yang diwujudkan melalui regulasi dan kebijakan pemerintah yang terkait dengan desa. Hal itu, pada akhirnya mengakibatkan kualitas perencanaan, pelaksanaan, pengedalian, dan pemanfaatan kegiatan pembangunan 
kurang optimal, sehingga kurang memberikan dampak terhadap peningkatan kesejahteraan masyarakat desa.

Merespon kondisi itu, Pemerintah sesuai amanat UU Desa, menyediakan tenaga pendamping profesional, yaitu: Pendamping Lokal Desa (PLD), Pendamping Desa (PD), sampai Tenaga Ahli (TA) di tingkat Pusat, untuk memfasilitasi pemerintah desa melaksanakan UU Desa secara konsisten.

Aspek lain yang juga harus diperhatikan secara serius dalam pengelolaan pembangunan desa adalah ketersediaan data yang memadai, menyakinkan, dan up to date, mengenai kondisi objektif maupun perkembangan Desa-Desa yang menunjukkan pencapaian pembangunan desa. Koreksi atas kelemahan/kekurangan dan upaya perbaikan terkait problematika atas pelaksanaan otonomi desa harus terus diupayakan oleh Kementerian Desa PDTT secara proaktif, salah satunya dengan meluncurkan Program Inovasi Desa (PID).

Program prioritas Menteri Desa PDTT, melalui peningkatkan produktivitas perdesaan dengan bertumpu pada:

1. Pengembangan kewirausahaan, baik pada ranah pengembangan usaha masyarakat, maupun usaha yang diprakarsai desa melalui Badan Usaha Milik Desa (BUMDes)

2. Peningkatan kualitas sumber daya manusia (SDM).

3. Pemenuhan dan peningkatan infrastruktur perdesaan, khususnya yang secara langsung berpengaruh terhadap perkembangan perekonomian Desa

\section{F. PENUTUP}

Penyelenggaraan pemerintahan desa merupakan subsistem dari sistem penyelenggaraan pemerintahan sehingga desa memiliki kewenangan dan mengurus kepentingan masayarakatnya melalui perencanaan pembangunan desa diselenggarakan dengan mengikut sertakan masyarakat desa melalui musyawarah perencanaan pembangunan desa, yang menetapkan prioritas, program, kegiatan dan kebutuhan pembangunan desa yang didanai oleh Anggaran Pendapatan dan Belanja Desa, swadaya masyarakat desa, dan/ atau Anggaran Pendapatan dan Belanja Daerah 
$e-I S S N$ : 2621-4105

kabupaten/Kota Pemerintah harus segera melakukan revisi berbagai aturan-aturan dalam UU Desa. antara lain terhadap norma hukum yang masih menimbulkan konflik baik vertikal maupun horizontal, norma hukum yang tidak jelas, norma hukum yang masih kosong, serta untuk meningkatkan kapasitas dalam menyelenggarakan pembangunan desa dengan menyediakan tenaga pendamping profesional.

\section{DAFTAR PUSTAKA}

\section{BUKU}

Amrusyi, Fahmi. 1987. Otonomi Dalam Negara Kesatuan, dalam Abdurrahman (editor), Beberapa Pemikiran Tentang Otonomi Daerah. Jakarta : Media Sarana Press Ali, Zainuddin. 2015. Metode Penelitian Hukum. Jakarta : Sinar Grafika Asshiddiqie, Jimly. 1994. Gagasan Kedaulatan Rakyat Dalam Konstitusi dan Pelaksanaannya Di Indonesia. Jakarta : PT Ichtiar Baru Van Hoeve Asshiddiqie, Jimly. Konstitusi dan Konstitualisme. 2006. Jakarta: Konstitusi Press Bintarto, R. 1993. Geografi Desa. Yogyakarta : Up Spring Busroh, A. Daud. 1993. Ilmu Negara. Jakarta : Bumi Aksara

Diantha, I. M. 2016. Metodologi Penelitian Hukum Normatif. Jakarta : Prenada Media Group.

Dwipayana, Ari. 2003. Membangun Good Governance Di Desa. Yogyakarta : IRE Press Gadjong A.S.A. 2007. Pemerintahan Daerah Kajian Politik Dan Hukum. Bogor : Ghalia Indonesia

Gie. Liang, The . 1969. Pertumbuhan Pemerintahan Daerah di Negara Republik Indonesia. Jakarta : Gunung Agung

Hadi, Sutrisno. 1987. Metodologi Riset Nasional. Magelang : Akmil

Hatta, Muhammad, dikutip dari Suhartono Dkk, Politik Lokal; Parlemen Desa: Awal Kemerdekaan Sampai Jaman Otonomi Daerah, Yogyakarta : Lapera Pustaka Utama

Huda, Ni'matul. 2015. Hukum Pemerintahan Desa; Dalam Konstitusi Indonesia Sejak Kemerdekaan Hingga Era Reformasi. Malang : Setara Press

Ina E. Slamet, dikutip dari Suhartono Dkk. 2001. Politik Lokal; Parlemen Desa: Awal Kemerdekaan Sampai Jaman Otonomi Daerah, Yogyakarta : Lapera Pustaka Utama

Juanda. 2004. Hukum Pemerintahan Daerah. Bandung : Alumni, 2004

Juliantara, Dadang. 2003. Pembaharuan Desa, Bertumpu Pada Angka Terbawah. Yogyakarta : Lappera Pustaka Utama.

Kansil, C.S.T. dan Christine.2004 Pemerintahan Daerah di Indonesia; Hukum Administrasi Daerah. Cetakan kedua. Jakarta : Sinar Grafika Offset. 
Mahmud, Peter. 2011. Penelitian Hukum. Jakarta : Rajawali Press.

Mamudji, S. S. 2007. Penelitian Hukum Normatif Suatu Tinjauan Singkat. Jakarta : Raja Grafindo Persada.

Marie un. 1975. Azas-azas Ilmu Pemerintahan.Yogyakarta : Fisip UGM

Moleong, L.J. 2000. Metodologi Penelitian Kualitatif. Bandung : PT. Remaja Rosdakarya

Nurcholis, H. 2011. Pertumbuhan dan Penyelenggaraan Pemerintahan Desa. Jakarta : Erlangga

Pambudi, H. 2011. Politik Pemberdayaan, Jalan Mewujudkan Otonomi Desa, Yogyakarta : Lapera Pustaka Utama

Pratikno. 2003. Cetakan III. Kompleksitas Persoalan Otonomi Daerah di Indonesia. Yogyakarta : Pustaka Pelajar

Ryaas Rasyid. 1997. Kajian Awal Birokrasi Pemerintahan Politik Orde Baru. Jakarta: Yarsif Watampone

Salahudin, M. 2015. Cetakan Pertama. Kewenangan Desa dan Regulasi Desa. Jakarta : Kemernterian Desa PDTT RI

Salam, D S. 2003. Otonomi Daerah Dalam Perspektif Lingkungan, Nilai dan Sumber Daya. Jakarta : Djambatan

Susanti, D.O. 2015. Penelitian Hukum (Legal Research). Jakarta : Sinar Grafika

Semarang, Pasca Sarjana. 2015. Panduan Penulisan Usulan penelitian dan Tesis. Semarang : Universitas Semarang.

Soehino. 2004. cetakan kedua. Hukum Tata Negara Perkembangan Otonomi Daerah. Yogyakarta: BPFE

Soemantri, Sri. M. 1981. Pengantar Perbandingan Antara Hukum Tata Negara. Jakarta : Rajawali

Syafrudin, Ateng. 1985. Pasang Surut Otonomi Daerah. Bandung : Binacipta

Tahir, Irwan, S.W. 2004. Cetakan Pertama. Prospek Pengembangan Desa. Bandung : CV Fokusmedia

Widjaja, H.A.W. 2008 Otonomi Desa : Merupakan Otonomi Yang Asli, Bulat dan Utuh. Jakarta : Rajawali Pers

\section{JURNAL dan ARTIKEL}

Septi Nur Wijayanti. 2016. Hubungan Antara Pusat dan Daerah Dalam Negara Kesatuan Republik Indonesia Berdasarkan Undang-Undang Nomor 23 Tahun 2014. Jurnal Media Hukum, Volume 23 Nomor 2, 186-199.

Zaenal Arifin. 2015. Implementasi Undang-Undang Nomor 32 Tahun 2004 Dan Undang-Undang Nomor 6 Tahun 2014 Terhadap Pelaksanaan Otonomi Desa Di Kabupaten Jepara. Semarang, Magister Ilmu Hukum Pasca Sarjana Universitas Sultan Agung

Gufron. 2016. Hubungan Antara Pemerintah Daerah dan Pemerintah Desa Dalam Konsep Otonomi Pasca Reformasi Di Indonesia. Yogyakarta, Magister Ilmu Hukum Pasca Sarjana Universitas Islam Indonesia 
e-ISSN : 2621-4105

\section{UNDANG-UNDANG}

Undang-Undang Dasar Negara Republik Indonesia Tahun 1945

Undang-Undang Nomor 22 Tahun 1999 Tentang Pemerintahan Daerah

Undang-Undang Nomor 32 Tahun 2004 Tentang Pemerintahan Daerah

Undang-Undang Nomor 23 Tahun 2014 Tentang Pemerintahan Daerah.

Undang-Undang Nomor 6 Tahun 2014 Tentang Desa

Undang-Undang Nomor 9 Tahun 2015 Tentang Perubahan Kedua Atas Undang-

Undanng Nomor 23 Tahun 2014 Tentang Pemerintahan Daerah.

Peraturan Pemerintah (PP) Nomor 72 Tahun 2005 Tentang Desa

Peraturan Pemerintah (PP) Nomor 43 Tahun 2014 Tentang Desa

Peraturan Pemerintah (PP) Nomor 60 Tahun 2014 Tentang Dana Desa Yang Bersumber Dari Anggaran Pendapatan Dan Belanja Negara.

Peraturan Menteri Dalam Negeri (Permendagri) Nomor 114 Tahun 2014 tentang Pedoman Pembangunan Desa.

Peraturan Menteri Keuangan Republik Indonesia Nomor 241 Tahun 2014 pasal 1 tentang Pelaksanaan Pertanggungjawaban Transfer ke Daerah dan Dana Desa.

Peraturan Kementerian Desa, Pembangunan Desa Tertinggal dan Transmigrasi Nomor 2 Tahun 2015 tentang Pedoman Tata Tertib dan Mekanisme Pengambilan Keputusan Musyawarah Desa 